\title{
EU-Turkey Energy Dialogue: Moving Beyond the Accession Negotiations Framework
}

\author{
Nicolò Sartori
}

\subsection{INTRODUCTION}

During the last two decades, both Europe and Turkey have perceived energy as a key area of mutual strategic interest. Before the political stalemate took hold at the end of the 2010s, Ankara and Brussels not only regarded energy as a domain of policy convergence but also considered it a fundamental platform upon which to strengthen their overall bilateral dialogue.

Energy security, ${ }^{1}$ specifically the diversification of gas supplies, is certainly one of the key areas of bilateral cooperation starting from the 2000s. Since 2003, Turkey has been at the center of the European

${ }^{1}$ The International Energy Agency (IEA) (2020) defines energy security as the uninterrupted availability of energy sources at an affordable price.

${ }^{2}$ The Southern Gas Corridor is an initiative launched by the European Commission to establish a pipeline network aimed at improving the security and diversity of the EU's energy supply by bringing to Europe natural gas from the Caspian and the broader Middle East region.

\footnotetext{
N. Sartori $(\varangle)$

University of Trento, Trento, Italy

e-mail: nicolo.sartori@enel.com

(C) The Author(s) 2021

W. Reiners and E. Turhan (eds.), EU-Turkey Relations, https://doi.org/10.1007/978-3-030-70890-0_15
} 
Union's (EU) most ambitious external energy policy initiative, the realization of the Southern Gas Corridor (SGC). ${ }^{2}$ Meanwhile, Ankara has repeatedly presented its 'contribution to Europe's energy security' as one of the key priorities of its own national energy strategy (Koranyi \& Sartori, 2013).

Despite such a strong focus, EU-Turkey energy dialogue has extended across a wide range of increasingly complex and sensitive issues beyond security of supply concerns, such as the convergence and integration of electricity and gas markets and their adaptation to ambitious decarbonization and sustainable development objectives undertaken at the EU and global levels. Although Brussels and Ankara have not yet been able to launch similarly strong initiatives in these domains, some cooperative bilateral efforts-e.g., in the case of electricity, market liberalization-have moved forward. The alignment of Turkey's energy legislation with the acquis communautaire is indeed a key factor to ensuring that Ankara will be able to become a fundamental enabler of energy security and a strategic energy partner for the EU for the benefit of both partners.

In this context, the chapter explores the evolution of energy relations between Turkey and the EU starting from the beginning of the 2000s, paying specific attention to the key energy policies and the main bilateral dynamics in place in the energy domain. It analyzes the energy profiles and interests of Brussels and Ankara in order to evaluate whether or not the EU and Turkey have adopted mutually beneficial initiatives that foster convergence ${ }^{3}$ between the parties. On the one hand, the chapter focuses on the longstanding debate on energy security and on the narrative of Turkey as an 'energy bridge'. ${ }^{4}$ On the other hand, it examines specific bottom-up technical/regulatory cooperation, the outcome of which can effectively foster the integration of the two markets, thereby guaranteeing more secure, competitive, and sustainable energy flows to European and Turkish citizens and firms. Finally, it assesses the results achieved by the

\footnotetext{
${ }^{3}$ The concept of convergence includes the alignment and joint definition of strategies, policies, and measures between the EU and Turkey in the energy domain.

${ }^{4}$ Due to its strategic location between abundant energy resources located in the Caspian/Middle Eastern region and the European markets, Turkey can play a role as 'bridge' (both in physical and political terms) to facilitate the oil and-particularly-gas transit from producers to consumers. While the term 'bridge' mainly refers to Turkey's transit role, the concept of 'hub' defines the capacity of the country to play an either physical or virtual trading role between producers and consumers but also consumers themselves.
} 
institutional initiatives established by Brussels and Ankara in order to strengthen cooperation in the energy domain, including the effort to engage Turkey in the framework of the 'Energy Community', the launch of the 'EU-Turkey Positive Agenda' and the 'EU-Turkey High Level Energy Dialogue and Strategic Energy Cooperation'.

\subsection{Energy Profiles and Policies}

The EU and Turkey are engaging in necessary energy transition processes driven by decarbonization commitments and technological developments. Both are organizing their energy policies around the same three key objectives: competitiveness, security of supply, and sustainability. ${ }^{5}$ However, due to different energy profiles (i.e., energy sources available; demand growth patterns) and diverse priorities regarding time and varying levels of ambition toward realizing these three objectives, the energy policy convergence between the two partners is still partial and limited to certain domains.

Looking at Europe, since the end of 2009 the EU economy has struggled to fully recover, with clear implications for energy demand. Due to the joint effects of the economic crisis and its ambitious decarbonization policies, the EU's primary energy consumption dropped dramatically from its 2006 peak; in 2014, it reached levels last seen before the 1990s, only slightly rebounding since 2015 (Eurostat, 2017). According to forecasts from the European Commission (EC), the bloc's energy demand is projected to decline steadily until 2040 , at which time it is likely to stabilize (European Commission, 2016a).

Responding to these significant energy transformations, in 2015 the Commission's Energy Union strategy crystalized the EU's multidimensional approach aimed at transforming the EU's current fossil fuel-based, centralized, and outdated energy system into one which is low-carbon, flexible, and efficient. The EU's approach is based on five mutually reinforcing and closely interrelated dimensions: energy security (where

\footnotetext{
5 Since the release of the 'Green Paper: A European strategy for sustainable, competitive and secure energy' (European Commission, 2006), the EU has based its energy policy on the three pillars 'competitiveness', 'security', and 'sustainability'. In Turkey the three concepts are identified as the main elements of the national energy strategy (Republic of Turkey Ministry of Foreign Affairs, 2011).
} 
EU-Turkey relations are expected to play a key role); market integration; energy efficiency; decarbonization; research, innovation, and competitiveness (European Commission, 2015a).

In such a context of declining demand and growing concerns about the effects of climate change, the EU committed itself to an increasingly ambitious process of energy transition and decarbonization. Europe is the prime mover and global leader in the fight against climate change, and it expects to maintain this role in the years and decades to come, as confirmed during the United Nations Conference of the Parties (COP21) held in Paris in December 2015 (UNFCCC, 2015a). This was reiterated in the debate on the 2050 Long-term Strategy, offering a vision for a prosperous, modern, competitive, and climate-neutral economy by 2050 (European Commission, 2018a). This objective is further strengthened by the 'European Green Deal' initiative launched in 2019 by the new von der Leyen Commission. The Green Deal aims at radically transforming the entire European socio-economic system, starting from the energy sector, in order to become a carbon neutral economy by 2050 (European Commission, 2019a). At the same time, Brussels is wholly focused on the liberalization of member states' energy markets and their full integration into a unique single European market, the realization of which represents a precondition for any effective energy security effort-which remains, in any case, high on the agenda at the EU level.

In regard to Turkey, from 2000 to 2014 Turkey was one of the fastest growing economies in the world, with annual growth rates averaging around $5 \%$. In this context of economic vitality, energy demand skyrocketed: electricity consumption increased by almost $90 \%$, while gas demand grew from 22 billion cubic meters (bcm) to $49 \mathrm{bcm}$ in this period (Enerdata, 2019). Over the last few years Turkey's economy has slowed down compared to the boom started in the $1990 \mathrm{~s},{ }^{6}$ but energy fundamentals remain strong as well as the concerns about the sustainability of the country's energy sector. This is, first, because energy demand, despite macro-economic trends, is projected to expand at a fast pace so as to satisfy not only economic activities but also the increasing living standards of Turkish citizens. Second, the dependence of Turkey on external hydrocarbon supplies (imports already account for $91 \%$ of

\footnotetext{
${ }^{6}$ From 2004 to 2014 the GDP of Turkey grew-excluding the effects of the 2008 financial crisis-on average, by $8 \%$ per year. Since 2014 the Turkish economy experienced a relevant degree of volatility, with GDP growth bottoming to $3.2 \%$ in 2016 .
} 
total oil demand and $99 \%$ of domestic gas consumption) is expected to continue and possibly increase (Şengül, 2019).

In the context of Turkey's extreme dependence and vulnerability vis$\grave{a}$-vis exporters, Ankara's focus on policies toward energy security and diversification of supply at the domestic, regional, and international levels is sensible (Republic of Turkey Ministry of Energy and Natural Resources, 2014a). To achieve this, Ankara envisages, on the one hand, the deployment of nuclear plants and the revival of coal-based electricity generation promoted by a new energy strategy (Anadolu Agency, 2017), which is expected to satisfy the country's growing electricity demand and reduce natural gas usage. On the other hand, Ankara has developed an ambitious regional integration plan centered on the transit of hydrocarbons. In the oil sector, such a plan was materialized thanks to the Baku-Tbilisi-Ceyhan pipeline in 2006 and the Kurdistan Regional Government pipeline in 2013. In the gas domain, the realization of the Trans-Anatolian Natural Gas Pipeline (TANAP) - transporting resources from Azerbaijan and, potentially, from other sources in the Eastern Mediterranean and the Middle East-is the cornerstone of Turkey's strategy to diversify its supply and, potentially, to becoming a regional gas trading hub.

Along with energy security initiatives, Turkey is moving aheadthough at a different pace and with different levels of ambition-on EU-inspired market reforms and decarbonization policies. In particular, Ankara has achieved significant results in the electricity sector's liberalization process, as Turkey's adoption of a new Electricity Market Law in 2013 (Official Gazette, 2013) is largely compliant with the EU's Third Energy Package (TEP). ${ }^{7}$ The situation is different with gas as the Gas Market Law adopted in 2001 (Official Gazette, 2001) has yet to be fully implemented, and moreover, its amendment process - in order to comply with the new rules introduced by the TEP in 2009-has been blocked in the Turkish Grand National Assembly since 2014.

Finally, in line with its 'Vision 2023' strategy, the Turkish government adopted a set of mid-term energy targets further defined in a number of

${ }^{7}$ Adopted in 2009, the Third Energy Package consists of two directives and three regulations. The directives concern common rules for the internal market in gas $(2009 / 73 / \mathrm{EC})$ and for the internal market in electricity $(2009 / 72 / \mathrm{EC})$. The three regulations concern the conditions for access to the natural gas transmission networks ([EC] No. 715/2009), the conditions for access to the network for cross-border exchange of electricity ([EC] No. 714/2009), and the establishment of the Agency for the Cooperation of Energy Regulators (ACER) ([EC] No. 713/2009). 
national action plans on energy efficiency, renewable energy, and climate change. Turkey's objective is to increase its share of renewable energy in the electricity generation mix to at least $30 \%$, increasing wind power up to $20 \mathrm{GW}$ and solar up to $3 \mathrm{GW}$ (Republic of Turkey Prime Ministry, n.d.). In addition, the government set a $20 \%$ energy efficiency target for the period from 2011 to 2023 . Regarding the fight against climate change, at the COP21 Turkey committed to a reduction of up to $21 \%$ of its greenhouse gas emissions by 2030 (UNFCCC, 2015b). This target, however, is not considered to be in line with interpretations of a fair approach to reaching a $2{ }^{\circ} \mathrm{C}$ pathway and is well below the country's effective decarbonization potential (Climate Action Tracker, 2019). Despite these plans, the implementation of decarbonization policies is partial and largely remains on paper, as demonstrated by Turkey's unwillingness to ratify the Paris Agreement and its renewed emphasis on the use of lignite and coal by then Turkish Minister of Energy and Natural Resources Berat Albayrak and confirmed by the current minister, Fatih Dönmez (Hürriyet Daily News, 2018).

\subsection{Turkey's CONTRiBution to European Energy Security}

As already stressed, in the last two decades EU-Turkey bilateral cooperation in the energy domain has mainly focused on security of supply, specifically on the diversification of gas sources, as a result of the need of both parties to access new, secure sources of gas and to open transit routes.

With the rapid emergence of energy security concerns in the EU at the beginning of the 2000s, the value of Turkey as an energy bridge between East and West appeared clear. In this context, the EC's launch of the SGC-the pipeline network running from the gas-rich Caspian basin to the EU, thereby bypassing Russian territory-in 2003 expanded the EU's energy cooperation with Turkey to the gas sector and granted Ankara a central role in Europe's energy diversification strategy. 8 Meanwhile,

\footnotetext{
${ }^{8}$ The key role of Turkey as a transit country first resulted in the implementation of the 1994 international agreement on the joint development of the ACG oil fields in the Azerbaijani sector of the Caspian Sea. The transit through Turkish territory allowed Azerbaijani oil to bypass the congested Bosphorus, ensuring a secure and profitable way to reach international markets.
} 
Turkey's outstanding economic growth led to the previously mentioned extraordinary increase in domestic energy demand, forcing Ankara to expand its gas supplies from abroad, particularly from Russia, which became the top energy provider for the Turkish market. Given the political drift between Russia and the EU following the 2013 Ukraine crisis, strengthening energy ties between Moscow and Ankara became a major concern for Brussels' agenda. Growing anxiety about the use of Russia's energy abundance as a weapon aimed at Europe encouraged Brussels to develop its first ever Energy Security Strategy and to establish the Energy Union initiative. The strengthening of ties with Ankara, with the main goal to limit Moscow's energy leverage on its member states (particularly in Central and Eastern Europe), was part of this vision (European Commission, 2014a).

From the Turkish perspective, energy cooperation-particularly the realization of the SGC as a key element of Ankara's strategic relations with the EU-has been progressively revised over the past twenty years. In the first decade of the new century, high level officials in Ankara repeatedly stressed Turkey's indispensable role for European energy security and its contribution to strengthening the country's position in the EU accession process. Up until 2010, the 'membership perspective and the [... accession negotiations with the EU [have been] a driving force for the realization of joint projects which will enhance the supply security of Turkey and the EU' (Koranyi \& Sartori, 2013: 4). However, the progressive freezing of negotiations and the uncertain status of the accession process-considering the high political value Ankara attaches to energy cooperation with the EU-have negatively impacted the evolution of the bilateral energy dialogue. Although formal institutional cooperation frameworks and initiatives are still in place and the role of Turkey as a key transit country has never been called into question, the balance of power between regional actors has effectively changed the trajectory of the SGC. Throughout the last decade, the nature of the Corridor has been reviewed on a number of occasions for political, geographical, industrial, and commercial reasons, and its current structure is very different from the one initially envisaged.

According to Brussels' original plans dating back to 2003, the Corridor was supposed to be based on 'the integration of multiple pipeline systems which would [have] transport [ed] gas not from a single supplier but from multiple sources' (Demiryol, 2013: 116). In theory, these sources had 
to include not only Azerbaijan, but also Iran, Iraq, and other potential suppliers from the broader Middle East and North Africa region. In the Commission's original proposal, the flagship project to enable the SGC was the $3825-\mathrm{km}$ Nabucco pipeline, aimed to deliver $31 \mathrm{bcm}$ annually to Southeast and Central Europe (RWE, 2009). Turkey's territory, which the pipeline would cross from east to west, was central to enabling the plan and delivering the Caspian gas supplies to the city of Baumgarten in Austria. However, due to commercial and financial shortcomings - namely the lack of supplies in the early years and the insufficient gas demand in the Central European target markets-Nabucco (and its successor initiative, Nabucco West ${ }^{9}$ ) failed to gain the support of the Shah Deniz-producing consortium and was aborted. As an alternative to Nabucco, the Trans-Adriatic pipeline (TAP) was selected to deliver Azerbaijani gas from the Turkish/Greek border to Italy via Greece and Albania (Sartori, 2013).

Turkey, the strategic priorities of which had changed during the years, played a direct role in determining the Nabucco's death sentence: Ankara was in fact first in line, along with Azerbaijan, in proposing the realization of TANAP ${ }^{10}$ which effectively replaced Nabucco for the transportation of Shah Deniz gas from the Georgian-Turkish border to the Turkish-European one (where it connects to TAP). The Turkish company BOTAŞ, with $30 \%$ of the shares, is one of the key stakeholders in the $16-\mathrm{bcm} / y e a r$ pipeline (which will gradually be increased to $24 \mathrm{bcm}$ ). Other companies involved include the Baku-controlled Southern Gas Corridor Closed Joint Stock Company, with 58\% of the shares, and British Petroleum with $12 \%{ }^{11}$

The launch of TANAP certainly boosted the implementation of the SGC, frustrated for years by the commercial fragility of Nabucco. At

\footnotetext{
${ }^{9}$ In May 2012, the Nabucco consortium revised its original plan, putting forward a shorter, cheaper, and less capable pipeline-Nabucco West-to transport Azerbaijani gas from the Turkish-Bulgarian border to Central Europe.

${ }^{10}$ The realization of TANAP was sanctioned by the signature of a memorandum of understanding between Azerbaijan and Turkey on 24 December 2011, followed by an intergovernmental agreement and the 'Host Government Agreement' on 26 June 2012.

${ }^{11}$ The SGC was created under the terms of an Azerbaijani presidential decree as the vehicle to consolidate, manage, and finance the country's interests in relation to Shah Deniz, SCP, TANAP, and TAP. The Republic of Azerbaijan, through its ministry of economy, owns $51 \%$ of the SGC's equity, while the remaining $49 \%$ is held by the State Oil Company of the Azerbaijan Republic (SOCAR) which is entirely owned by Azerbaijan.
} 
the same time this represented a significant turn from the plan initially conceptualized by Brussels. In the new framework, upstream companies that are members of the Shah Deniz consortium took center stage of the SGC initiative, replacing the group of European companies expected to run Nabucco and control the transport of the gas supply from Azerbaijan to Europe. Due to changing domestic energy priorities, particularly relating to the need to secure additional volumes of gas, and intensified political clashes with the EU, Turkey revised the nature of its contribution to the SGC. This shift contributed to downscaling the EU's role in the regional energy game, with potentially disadvantageous long-term consequences for both Turkey and the EU as gas customers vis- $\grave{a}$-vis an empowered Azerbaijan.

Despite the reshuffle of the Corridor, regional energy cooperation remains a mutual area of interest for both the EU and Turkey, which are trying to keep the subject at the top of their energy agenda. This was initially demonstrated by the 'EU-Turkey High Level Energy Dialogue and Strategic Energy Cooperation' launched in 2015 as a platform for regular exchange of information on energy cooperation at the global and regional level for the benefit of both sides (Tagliapietra \& Zachmann, 2015). However, the High Level Energy Dialogue was then blocked after the rising tensions between the EU and Turkey given the developments in the Eastern Mediterranean.

The Eastern Mediterranean is indeed a matter that could lead to a new low in bilateral energy cooperation (Tziarras, 2019). Tensions in the region started to rise after a number of gas discoveries were made by Eni and ExxonMobil off the coast of Cyprus between 2018 and 2019. Consequently, Ankara decided to dispatch drilling exploration ships escorted by Turkish military vessels in the area in order to run exploration activities in waters claimed by the Republic of Cyprus (Küçükgöçmen, 2019).

\subsection{Institutional Dialogue and Political Developments}

As mentioned above, Turkish authorities have constantly associated bilateral energy cooperation with Ankara's EU accession process. Energy is among the 35 policy areas of the acquis communautaire, also called 'chapters', covered by the negotiation process in place between the EU and Turkey since October 2005 (see also Lippert, Chapter 11). Negotiations 
on the energy chapter (also known as Chapter 15) cover EU legislation related reform of the internal electricity and natural gas markets, the implementation of energy efficiency measures, the integration of renewable energy resources in the energy mix, the strengthening of security of energy supply policies, and the improvement of nuclear safety.

Turkey's expectation to become a member of the EU has been a driving factor in its efforts to restructure the national energy sector. Since 2001, Ankara has been taking important steps toward this by adopting and implementing a number of EU-derived regulations in order to ensure its compliance with the acquis and to establish liberalized and competitive market structures and a business-friendly environment. These include the adoption of the Electricity Market Law No. 4628 and the Natural Gas Market Law No. 4646, together with the establishment of the Energy Market Regulatory Authority (EMRA) in 2001. ${ }^{12}$ The government also introduced laws for the Utilization of Renewable Energy Resources (No. 5325 ) in $2005^{13}$ and for Energy Efficiency (No. 5627) in 2007. ${ }^{14}$ The 2015 adoption of the Law No. 6446 amending the electricity market legislation contributed to significant improvements in the sector. ${ }^{15}$

Despite evident mutual interests, the advancements achieved, and the periodic institutional calls both from Brussels and Ankara for the opening of the energy chapter, negotiations on this chapter have been blocked by Cyprus since 2009, and the screening report adopted in 2007 was vetoed

${ }^{12}$ These laws aim at liberalizing the electricity and natural gas markets, respectively, in order to create financially sound, stable, and transparent markets and to ensure supply of electricity and natural gas at competitive prices to consumers in a regular and environmentally sound manner under competitive conditions.

${ }^{13}$ The law aims to expand the utilization of renewable energy sources for generating electric energy, encompassing the procedures and principles of the conservation of renewable energy resource areas, and certification of the energy generated from these sources as well as utilization of these sources.

${ }^{14}$ The law covers principles and procedures applicable to increasing and promoting energy efficiency in energy generation, transmission, distribution and consumption phases at industrial establishments, buildings, power generation plants, transmission and distribution networks and transport.

15 The new law does not abolish the former Electricity Market Law 4628 but instead reorganizes the former law to regulate the powers and duties of the Energy Market Regulatory Authority (EMRA), introducing new measures such as the pre-licensing system for generation companies and the Energy Market Operation Corporation (EPIAŞ) to carry out the market operation activities. 
by Cyprus in the Council of the EU. ${ }^{16}$ In addition to this, since the middle of the 2010s the entire accession negotiation process has experienced significant delays due to weakening bilateral relations between the EU and Turkey, culminating in the 2016 European Parliament's resolution which called on the Commission and the member states to initiate a temporary freeze of the ongoing accession negotiations with Turkey' (European Parliament, 2016: para. G.1; see also Kaeding \& Schenuit, Chapter 10). The resolution was followed by a number of decisions adopted by the Council, including the conclusions to halt any kind of progress on the chapters (Council of the EU, 2018) and to suspend all high level dialogues, including the one related to energy, after the aggressive approach adopted by Ankara in the Eastern Mediterranean (Council of the EU, 2019). Despite attempts to keep the dialogue alive, one cannot be fully optimistic about future prospects for formal EU-Turkey energy cooperation in such a political landscape. Not opening the energy chapter naturally encourages a less cooperative stand on this issue by Ankara, as demonstrated in the case of the SGC and TANAP. The political and institutional stalemate places limits on the scope and timing of EU-Turkey energy policy coordination as well as on the market, which requires crossborder infrastructure together with a stable, transparent common legal and regulatory framework, particularly in the sensitive gas sector.

In order to bypass the political bottlenecks slowing down the transfer and implementation of EU energy legislation in Turkey, Brussels and Ankara have tried to adopt alternative institutional initiatives in order to promote energy cooperation outside the framework of accession negotiations. Brussels' attempt to persuade Turkey to join the Energy Community - whose contracting parties commit themselves to implementing the relevant EU acquis on energy, environment, and competition-has been the first EU attempt to decouple deeper energy cooperation from the accession process. ${ }^{17}$ But throughout the years, the EU initiative has been

${ }^{16}$ The screening report results from the screening analysis, through which EU legislation in the relevant chapters and Turkish legislation are compared, with the report identifying those areas where compliance is high and those where further policy and legal harmonization is expected. The screening report forms the very basis of the Commission's Draft Common Position for the chapters to be negotiated (see also Lippert, Chapter 11).

${ }^{17}$ The Energy Community Treaty, in force since June 2006, is an EU initiative to extend internal energy market toward third countries in the Eastern and South Eastern neighborhood in order to enhance full market integration. Along with the EU, contracting parties include Albania, Bosnia-Herzegovina, the Republic of North Macedonia, Kosovo, 
repeatedly rejected by Ankara, which refused (and keeps refusing) the idea of unilaterally aligning with EU energy legislation as it prefers to link the process to deeper political dialogue with Brussels in the perspective of full EU membership status (Aydın-Düzgit \& Tocci, 2015). For the Turkish government, the Energy Community option would be adequate for countries not eligible for EU membership but not for an accession candidate such as Turkey. Candidate countries are expected to align with the EU energy acquis through the energy chapter negotiations and not in the framework of a parallel cooperation framework such as the Energy Community.

With an eye to overcoming Turkey's concerns about its participation in the Energy Community as an alternative to accession and the stand-off in negotiations, in May 2012 Brussels launched the 'EU-Turkey Positive Agenda' (European Commission, 2012a). The objective of the initiative was to reinforce accession talks by fostering cooperation and practical activities in a set of sectors of mutual interest, including energy. ${ }^{18}$ The focus on energy was confirmed by the June 2012 joint statement of EU Commissioners Günther Oettinger and Štefan Füle with then Turkish Ministers Egemen Bağış and Taner Yıldız, titled 'Turkey-EU Positive Agenda: Enhanced EU-Turkey Energy Cooperation' (European Commission, 2012b). The Agenda covered six areas of mutual concern, aiming to contribute to deepening bilateral energy relations through the following areas: long-term perspectives on energy scenarios and energy mix; market integration and development of infrastructures of common interest; global and regional energy cooperation; promotion of renewable energy; energy efficiency and clean energy technologies; nuclear safety and radiation protection. Turkish authorities perceived the launch of the EU-Turkey Positive Agenda initiative as a renewed European attempt to dissociate energy cooperation from the increasingly problematic issue of Turkey's accession to the EU. Despite the attempts of the Commission to clarify that the Agenda was not aimed at replacing Turkey's accession process but rather at supporting the country's integration into the EU

Moldova, Montenegro, and Serbia. Georgia is currently a candidate country, while Armenia, Norway, and Turkey maintain their observer status.

${ }^{18}$ Other areas of cooperation addressed by the EU-Turkey Positive Agenda include political reforms, alignment with the acquis, dialogue on foreign policy, visas, mobility and migration, trade, counterterrorism, and participation in EU programs. 
energy system, the initiative has been unsuccessful since the beginning (see also Bürgin, Chapter 9).

In order to revitalize institutional cooperation in the energy domain within the context of mounting political distrust, in March 2015 Commission Vice President Maros Sefcovic and former Turkish Minister for Energy and Natural Resources Taner Yildız launched the aforementioned EU-Turkey High Level Energy Dialogue and Strategic Energy Cooperation. Again, the parties tried to emphasize that the initiative aims to complement and support Turkey's accession process and does not seek to substitute or bypass it. The success of the initiative is, however, mixed-despite the initial optimism and the two meetings held between the end of 2015, in the context of the COP21 in Paris, and in 2016, when then Turkish Minister for Energy and Natural Resources Berat Albayrak and EU Commissioner for Climate Action and Energy Miguel Arias Cañete convened in Istanbul (European Commission, 2016b). Since 2016 no new meetings have been organized, while the meetings of all sectoral high level dialogues-included the energy-related one-remain suspended.

\subsection{EXPANDING COOPERATION Beyond Energy Security}

Despite the fluctuations and the current stalemate in the EU-Turkey institutional energy dialogue, bottom-up technical/regulatory cooperation keeps moving forward. In particular, market integration is progressively taking shape, specifically in the electricity domain, where the results achieved are particularly prestigious and have established concrete market convergence between Ankara and Brussels.

Trial activities for the synchronization of Turkey's electricity network with the Continental Europe System began on 18 September 2010, and five years later, in April 2015, the Turkish Electricity Transmission Company (TEİAŞ) and the continental European members of the European Network of Transmission System Operators for Electricity (ENTSOE) signed a long-term agreement on permanent synchronous operations. In this framework, TEİSS agreed to apply the network codes developed by the EU for the electricity market and their permanent connection to the Continental Europe Synchronous Area to allow free electricity trade 
through interconnections with Greece and Bulgaria. ${ }^{19}$ In addition, in January 2016 ENTSO-E granted 'observer member status' to TEİAŞ, a condition that allows the Turkish system operator to attend the meetings of the association's groups and task forces, thereby confirming its compliance with the acquis in most aspects of transmission system operations, including third party access rules and transmission network regulations, effective and market-based balancing mechanisms, and auctioning of interconnector capacities (included in Directive 2009/72/EC).

In the context of growing technical cooperation, in March 2014 TEIASS also contributed to the launch of the Coordination Auction Office in South East Europe (SEE CAO). SEE CAO is a joint network of ten Southeast European countries aimed at optimizing cross-border capacity allocation and harmonizing the different national congestion management methods from Croatia in the north to Turkey in the south. Since September 2015, the monthly interconnection capacities between Turkey and Greece have been allocated in a regionally coordinated manner through SEE CAO mechanisms, which in 2016 were extended to allocations of yearly bilateral capacities in order to strengthen cooperation.

As part of this progressive convergence with EU standards, over the last few years Turkey has privatized the distribution segment and most generation assets. In addition, thanks to the efforts of EMRA, 85\% of the market was opened in 2015 (World Bank, 2015). Organized wholesale operations in the market are carried out by EXIST (Energy Exchange Istanbul, EPİAŞ), the Turkish energy exchange, which operates day-ahead and intra-day electricity platforms, while the electricity transmission company TEIASS is now unbundled and the electricity distribution activities are privatized.

The integration of the European and Turkish gas markets remains partial, though some progress has occurred (European Commission, 2018b). Although the Turkish Natural Gas Market Law and the relevant secondary legislation adopted by Ankara are broadly in line with the main provisions of Directive 2003/55/EC on internal natural gas market liberalization (including some progress on tariffs and organized

${ }^{19}$ Under this scheme, Turkey can currently export 400 megawatts of electricity and import 550 megawatts of electricity from the European network, amounts that are expected to increase to 1000 megawatts in the future. 
wholesale markets) the acquis targets have not yet been fully achieved. ${ }^{20}$ In addition to this gap, it has to be stressed that the current Turkish legislation is not aligned with Directive $2009 / 73 / \mathrm{EC}^{21}$ as the new draft law aimed at enhancing competition on the natural gas market has been languishing in the Turkish Parliament without being discussed since 2014 . The unbundling of gas activities lags behind EU standards due to the national incumbent, BOTAŞ, that maintains a dominant position in the supply, trade, storage, wholesale, and transmission segments, as well as a large controlling share (between 80 and $90 \%$ ) of the country's import capacity. This situation has a negative impact not only on Turkey's ambition to become a regional gas-trading hub but also on the performance of the electricity market, as by June 2019 natural gas contributed to almost one-third of total power generation capacity (Republic of Turkey Ministry of Energy and Natural Resources, 2018).

A positive development was the launch of Turkey's natural gas spot trading platform in September 2018, operated by the EXIST Energy Exchange. The platform enables spot market transactions in natural gas, balancing transactions and reconciling imbalances, but its effectiveness is still limited by the dominant position of BOTAŞ in the Turkish market (European Commission, 2019b).

The integration of energy markets and the development of infrastructure are also supported within the framework of the EU's Instrument for Pre-accession Assistance (IPA) to Turkey (European Commission, $2014 b)$. Funds allocated through the IPA II (2014-2020) scheme aim to strengthen acquis alignment in the areas of electricity and gas, addressing in particular the modernization and upgrading of the Turkish Gas Transmission System in line with European Network of Transmission System Operators for Gas. This includes the soft supply equipment for the supervisory control and data acquisition system, as well as the harmonization of the Turkish gas and electricity codes with relevant EU network codes (European Commission, 2015b).

\footnotetext{
${ }^{20}$ Authorization in terms of licensing according to pre-defined, non-discriminatory conditions, legal unbundling of transmission activities from other energy activities, approval of regulated tariffs, and third-party access to networks, LNG and storage facilities by EMRA diminishing eligibility limits and settlement of disputes by EMRA.

${ }^{21}$ Unbundling of transmission operators, rules on designating a distribution system operator, combined operator, monitoring reports on security of supply, protection of vulnerable customers, exemptions concerning new infrastructure.
} 
Finally, EU-Turkey coordination is taking place-though at a much slower pace-also in the renewables and energy efficiency sectors. As a candidate country, in December 2014 Turkey published its National Renewable Energy Action Plan for the period 2013-2023. This was seen as a sign of Ankara's commitment to renewable energy objectives, thereby conforming to Directive 2009/28/EC and EU norms in general. The Action Plan analyzes the current situation and challenges to the development of renewable energy, identifies national targets, and defines the actions needed to achieve them (Republic of Turkey Ministry of Energy and Natural Resources, 2014b). In 2017, in order to comply with the Energy Efficiency Directive 2012/27/EU, Ankara published its National Energy Efficiency Action Plan. The plan expects the country to achieve a $14 \%$ reduction of primary energy consumption by 2023 , committing to investing almost 11 billion USD in energy efficiency measures to reach the target (Republic of Turkey Ministry of Energy and Natural Resources, 2017). In 2019, good progress was registered in the renewables sector with the launch of three large tenders in photovoltaics and onshore and offshore wind energy generation (European Commission, 2019b).

The effective establishment of cooperation mechanisms in the renewables sector depends on the degree of alignment with EU legislation and, in general, on the progression of the high level dialogue-the most adequate platform to advance strategic convergence in this domain. Adoption of the EU acquis would entail the necessity of Turkey to set an overall renewable energies target in line with the methodology applied to EU member states and the Energy Community Contracting Parties, in exchange for which the country would benefit from access to the cooperation mechanisms set up under EU legislation such as statistical transfers, joint projects, and joint support schemes. As an alternative to such formalized cooperation schemes, Art. 9 of the Directive 2009/28/EC refers to 'joint projects with third countries', which would allow Turkey (as well as other EU neighbors) to strengthen its (their) renewable energy sector through financial assistance, technological support, and/or capacity development.

\subsection{The Way Ahead}

At first glance, EU and Turkey energy interests and prioritiesmainly determined by the common 'security-sustainability-affordability' mantra-appear to be leading Brussels and Ankara down a virtuous path 
toward bilateral cooperation. However, the parties are still quite different in terms of their energy and climate profiles and far from fully aligned when it comes to key interests and policy priorities. The European Green Deal launched by the Commission in December 2019 further amplifies the diverging paths between Brussels and Ankara in this domain.

While the need for strengthening energy security and diversification of gas supplies justifies deepening ties between the EU and Turkey, progress in this domain remains uncertain due to Ankara's specific coupling of its role as Europe's energy security partner with the success of its EU accession negotiations. The realization of TANAP and the advancement in the completion of the SGC are certainly positive aspects of the EU-Turkey energy relationship. However, Ankara's full alignment with Europe's energy security priorities is far from reassuring, in particular in view of the rising tensions around Ankara's hydrocarbon exploration activities off the coast of Cyprus.

At the same time, however, bottom-up technical/regulatory collaboration has proved successful in strengthening bilateral energy relations between the EU and Turkey, as in the case of the progress registered in the electricity sector. Other, less debated sectors such as renewable energy, energy efficiency, nuclear energy, and carbon trading could benefit from a stronger push on developing bottom-up bilateral initiatives. On renewables and energy efficiency, the EU should scale up the financial support it currently provides within the framework of its climate finance commitments, while on carbon markets, Brussels can replicate what has been done, for instance, in China by increasing its institutional support to Ankara.

Only by undertaking these actions, and by decoupling energy cooperation from the formal accession negotiation process and high level political considerations, can EU-Turkey energy synergy become a positive factor in the strategic bilateral relationship between Brussels and Ankara. 


\section{REFERENCES}

Anadolu Agency. (2017, April 6). Turkey presents national energy strategy. https://www.aa.com.tr/en/economy/turkey-presents-national-energy-str ategy/790565. Accessed 29 Jul 2020.

Aydın-Düzgit, S., \& Tocci, N. (2015). Turkey and the European Union. London: Palgrave Macmillan.

Bürgin, A. (2021). The European Commission's role in EU-Turkey relations. Chapter 9 , in this volume.

Climate Action Tracker. (2019). Turkey: Country summary. https://climateactio ntracker.org/countries/turkey/. Accessed 9 Jun 2020.

Council of the European Union. (2018). Enlargement and stabilisation and association process, Council conclusions. 10555/18. Brussels, 26 June.

Council of the European Union. (2019). 3709th Council meeting, outcome of the council meeting. 11260/19. Brussels, 15 July.

Demiryol, T. (2013). The geopolitics of energy cooperation between Turkey and the European Union. L'Europe en Formation, 54(367), 109-134.

Enerdata-Energy Research eStore-Turkey. (2019). Data as of March 2019. https://estore.enerdata.net/turkey-energy.html. Accessed 4 Aug 2020.

European Commission. (2006). Green paper: A European strategy for sustainable, competitive, and secure energy. $\operatorname{COM}(2006) 105$ final. Brussels, 8 March.

European Commission. (2012a). Positive EU-Turkey agenda launched in Ankara. MEMO/12/359. Brussels, 17 May.

European Commission. (2012b). Turkey-EU positive agenda: Enhanced EUTurkey energy cooperation. https://ec.europa.eu/energy/sites/ener/files/doc uments/20120622_outline_of_enhanced_cooperation.pdf. Accessed 4 Aug 2020.

European Commission. (2014a). European energy security strategy. COM(2014) 330 final. Brussels, 28 May.

European Commission. (2014b). Instrument for pre-accession assistance (IPA II). Indicative Strategy Paper for Turkey (2014-2020), August 26. https://ec. europa.eu/neighbourhood-enlargement/sites/near/files/pdf/key_docume nts/2014/20140919-csp-turkey.pdf. Accessed 4 Aug 2020.

European Commission. (2015a). A framework strategy for a resilient energy union with a forward-looking climate change policy. $\operatorname{COM}(2015) 80$ final. Brussels, 25 February.

European Commission. (2015b). Instrument for pre-accession assistance (IPA II). 2014-2020. Turkey energy action document 2015. http://ec.europa.eu/enl argement/pdf/turkey/ipa/2015/ipa2015-038-405.7-energy.pdf. Accessed 4 Aug 2020. 
European Commission. (2016a). EU reference scenario 2016. Energy, transport and GHG emissions-Trends to 2050: Main results, July 20. https://ec.eur opa.eu/energy/sites/ener/files/documents/20160712_Summary_Ref_sce nario_MAIN_RESULTS\%20(2)-web.pdf. Accessed 4 Aug 2020.

European Commission. (2016b). Joint press statement. Turkey-EU High Level Energy Dialogue meeting. https://ec.europa.eu/energy/sites/ener/files/doc uments/ing\%20son.pdf. Accessed 9 Jun 2020.

European Commission. (2018a). A clean planet for all. A European strategic long-term vision for a prosperous, modern, competitive and climate neutral economy. $\operatorname{COM}(2018) 773$ final. Brussels, 28 November.

European Commission. (2018b). Turkey 2018 report. SWD(2018) 153 final. Strasbourg, 17 April.

European Commission. (2019a). The European green deal. $\operatorname{COM}(2019) 640$ final. Brussels, 11 December.

European Commission. (2019b). Turkey 2019 report. SWD(2019) 220 final. Brussels, 29 May.

European Parliament. (2016). European Parliament resolution of 24 November 2016 on EU-Turkey relations. P8_TA(2016)0450. Strasbourg, 24 November.

Eurostat. (2017). EU 28 energy consumption 1990-2015: Eurostat Statistics Explained. https://ec.europa.eu/eurostat/statistics-explained/index. php?title=File:Gross_inland_consumption_of_energy,_1990-2015_(million_t onnes_of_oil_equivalent)_YB17.png. Accessed 9 Jun 2020.

Hürriyet Daily News. (2018, October 12). Turkey transfers operating rights of seven coal fields to private companies. https://www.hurriyetdailynews.com/ turkey-transfers-operating-rights-of-seven-coal-fields-to-private-companies137794. Accessed 10 July 2020.

International Energy Agency. (2020). Energy security: Reliable, affordable access to all fuels and energy sources. https://www.iea.org/topics/energysecurity/. Accessed 9 Jun 2020.

Kaeding, M., \& Schenuit, F. (2021). The European Parliament's perspective on EU-Turkey relations. Chapter 10, in this volume.

Koranyi, D., \& Sartori, N. (2013). EU-Turkish energy relations in the context of EU accession negotiations: Focus on natural gas (Global Turkey in Europe Working Paper, No. 5). https://www.iai.it/sites/default/files/GTE_WP_05. pdf. Accessed 9 Jun 2020.

Küçükgöçmen, A. (2019, October 5). Turkish ship to begin drilling off Cyprus. Reuters. https://www.reuters.com/article/us-cyprus-turkey-ship/tur kish-ship-to-begin-drilling-off-cyprus-minister-idUSKCNIWK060. Accessed 9 Jun 2020.

Lippert, B. (2021). Turkey as a special and (almost) dead case of EU enlargement policy. Chapter 11, in this volume. 
Official Gazette. (2001). Natural gas market law No. 4646 (2001). http:// www.lawsturkey.com/law/natural-gas-market-law-law-on-the-natural-gas-mar ket-and-amending-the-law-on-electricity-market-4646. Accessed 9 Jun 2020.

Official Gazette. (2013). Electricity market law No. 6446 (2013). http://www. lawsturkey.com/law/electricity-market-law-6446. Accessed 9 Jun 2020.

Republic of Turkey Ministry of Energy and Natural Resources. (2014a). Strategic plan 2015-2019. https://www.enerji.gov.tr/File/?path=ROOT\%2F1\%2FD ocuments\%2FStrategic+Plan\%2FStrategicPlan2015-2019.pdf. Accessed 9 Jun 2020.

Republic of Turkey Ministry of Energy and Natural Resources. (2014b). National renewable energy action plan for Turkey. https://www.ebrd.com/ documents/comms-and-bis/turkey-national-renewable-energy-action-plan. pdf. Accessed 2 Aug 2020.

Republic of Turkey Ministry of Energy and Natural Resources. (2017). National energy efficiency action plan (NEEAP) 2017-2023. http://www.resmigazete. gov.tr/eskiler/2018/01/20180102Ml-1-1.pdf. Accessed 9 Jun 2020.

Republic of Turkey Ministry of Energy and Natural Resources. (2018). Electricity statistics. https://web.archive.org/web/20200429022532/https:// www.enerji.gov.tr/en-us/pages/electricity. Accessed 29 Jul 2020.

Republic of Turkey Ministry of Foreign Affairs. (2011). Turkey's energy profile and strategy. http://www.mfa.gov.tr/turkeys-energy-strategy.en.mfa. Accessed 9 Jun 2020.

Republic of Turkey Prime Ministry. (n.d.). Turkey vision 2023. http://www. turkey-japan.com/business/categoryl/categoryl_70.pdf. Accessed 27 Nov 2020.

RWE. (2009). Die Gas-Pipeline Nabucco: 'der vierte Korridor nach Europa'. Press release. 11 September 2009.

Sartori, N. (2013, July 27). Energy and politics: Behind the scenes of the NabuccoTAP Competition (IAI Working Papers No. 13). https://www.iai.it/sites/def ault/files/iaiwp1327.pdf. Accessed 27 Nov 2020.

Şengül, E. (2019, February 6). Turkey's energy import bill up $15.6 \%$ in 2018. Anadolu Agency. https://www.aa.com.tr/en/energy/finance/turkeysenergy-import-bill-up-156-in-2018/23378. Accessed 9 Jun 2020.

Tagliapietra, S., \& Zachmann, G. (2015, July 1). Designing a new EU-Turkey strategic gas partnership. Bruegel Policy Contribution. https://www.bru egel.org/2015/07/designing-a-new-eu-turkey-strategic-gas-partnership/. Accessed 27 Nov 2020.

Tziarras, Z. (Ed.). (2019). The new geopolitics of the Eastern Mediterranean: Trilateral partnerships and regional security. Re-Imagining the Eastern Mediterranean Series PCC Report 3/2019. Friedrich-Ebert-Stiftung and Peace Research Institute Oslo. 
UNFCCC. (2015a). Paris agreement. https://unfccc.int/sites/default/files/eng lish_paris_agreement.pdf. Accessed 9 Jun 2020.

UNFCCC. (2015b). Republic of Turkey intended nationally determined contribution. https://www4.unfccc.int/sites/submissions/INDC/Published\%20D ocuments/Turkey/1/The_INDC_of_TURKEY_v.15.19.30.pdf. Accessed 9 Jun 2020.

World Bank. (2015). Turkey's energy transition milestones and challenges. http:// documents.worldbank.org/curated/en/249831468189270397/pdf/ACS 14951-REVISED-Box393232B-PUBLIC-EnergyVeryFinalEN.pdf. Accessed 9 Jun 2020.

Nicolò Sartori is senior researcher at the Enel Foundation, Rome. He is also an adjunct professor at the University of Trento and at the LUMSA University. He holds a B.A. in International and Diplomatic Studies from the School Roberto Ruffilli in Forlì and an M.A. in International Relations from the University of Bologna. At the time of writing, he was the head of the 'Energy, Climate and Resources' Program at the Italian think tank Istituto Affari Internazionali (IAI), Rome. He also served as faculty advisor at the NATO Defense College in Rome, where he conducted research on NATO's role as energy security provider in the Caspian region.

Open Access This chapter is licensed under the terms of the Creative Commons Attribution 4.0 International License (http://creativecommons.org/licenses/ by $/ 4.0 /)$, which permits use, sharing, adaptation, distribution and reproduction in any medium or format, as long as you give appropriate credit to the original author(s) and the source, provide a link to the Creative Commons license and indicate if changes were made.

The images or other third party material in this chapter are included in the chapter's Creative Commons license, unless indicated otherwise in a credit line to the material. If material is not included in the chapter's Creative Commons license and your intended use is not permitted by statutory regulation or exceeds the permitted use, you will need to obtain permission directly from the copyright holder.

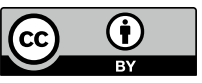

